\title{
Production of mouse monoclonal antibodies to Pasteurella multocida type A and the immunological properties of a protective anti-lipopolysaccharide antibody
}

\author{
THULA G. WIJEWARDANA*, CHRISTINA F. WILSON, N. J.L. GILMOUR and I. R. POXTON† \\ Moredun Research Institute, 408 Gilmerton Road, Edinburgh EH17 7JH and +Department of Bacteriology, \\ University Medical School, Teviot Place, Edinburgh EH8 9AG
}

\begin{abstract}
Summary. Eight monoclonal antibodies (MAbs) were produced from mice immunised with whole cells of heat-killed Pasteurella multocida type A which had been cultured under iron-restricted conditions. The MAbs were selected by an enzyme-linked immunosorbent assay (ELISA) in which the antigen consisted of whole bacteria of the immunising strain. Their reactivity was investigated further by immunoblotting, indirect haemagglutination, a complement-mediated bactericidal assay and passive protection of mice. One of the eight MAbs was shown by immunoblotting to react with lipopolysaccharide (LPS), was bactericidal, and completely protected mice against homologous challenge with $10 \mathrm{LD} 50$ of live bacteria. This MAb was selected for further study. Its reaction with LPS of 17 type-A strains and of single strains of types B, D and E was investigated by immunoblotting. Strains that reacted with the anti-LPS MAb in immunoblots were susceptible to its bactericidal activity and gave high ELISA absorbances. Those that did not react were not susceptible to its bactericidal activity and gave low ELISA readings. The relation between bactericidal activity and ELISA absorbance was highly significant $(\mathrm{p}<0 \cdot 001)$. Five of the strongly reacting heterologous strains and one non-reacting strain were selected as challenge organisms in a passive protection experiment: only the mice receiving the reacting strains were protected.
\end{abstract}

\section{Introduction}

Pasteurella multocida is the cause of various diseases in mammalian and avian species. ${ }^{1}$ Capsular type-A strains cause fowl cholera, pneumonia in cattle, sheep and pigs, and "snuffles" in rabbits; ${ }^{1,2}$ strains of types B and E cause haemorrhagic septicaemia in cattle and buffaloes; ${ }^{3}$ and type-D strains cause pneumonia in cattle and atrophic rhinitis in pigs. ${ }^{1,4}$

Capsular polysaccharides of $P$. multocida types B and $E$ are protective against haemorrhagic septicaemia. ${ }^{5}$ However, non-capsulate and capsulate organisms are equally effective in immunising birds against fowl cholera. ${ }^{6}$ Lipopolysaccharide (LPS) of $P$. multocida, which is considered to be responsible for the somatic serotype specificity, ${ }^{7}$ was poorly

Received 9 May 1990; accepted 25 June 1990.

*Present address: Veterinary Research Institute, PO Box 28, Gannoruwa, Peradeniya, Sri Lanka.

Correspondence should be sent to Dr I. R. Poxton. immunogenic in mice in its purified form, but protective in chickens. ${ }^{8}$ A protein-LPS complex protected mice, rabbits and chickens. ${ }^{9,10}$ LPS has been recognised as the major immunogen in ribosomal vaccines. ${ }^{11,12}$ The role of outer membrane proteins (OMP) in protection against $\boldsymbol{P}$. multocida infections is unclear. In mice, protection by whole-cell type-A vaccines was unrelated to their content of OMP $;^{13}$ in rabbits, however, a 37-5-KDa OMP has been identified as a protective antigen, but only against the strains that produce it. $^{14,15}$

\section{Materials and methods}

\section{Bacterial strains}

$P$. multocida strain W674, a calf pneumonia isolate, was used to immunise mice for MAb production. The National Collection of Type Cultures supplied strains of capsular serotypes A (NCTC 10322), B (NCTC 10323), D (NCTC 10325) and E (NCTC 10326). All other strains 
were of $P$. multocida type A, isolated from calves at Veterinary Investigation Centres and submitted to the Moredun Institute for identification as described previously. ${ }^{16}$

\section{Immunisation procedure and production of monoclonal antibodies}

Five 6-week-old BALB/c mice were immunised with $10^{8}$ heat-killed $\left(60^{\circ} \mathrm{C}, 90 \mathrm{~min}\right)$ cells of strain W674, grown in nutrient broth (NB; Oxoid) containing 2,2'-dipyridyl; the iron-restricted medium probably increased the resemblance of the bacteria to those grown in vivo. A suspension of washed bacteria $\left(8.0 \times 10^{9} / \mathrm{ml}\right.$ in PBS) was emulsified with an equal volume of Bayol/Arlacel adjuvant. One volume of the emulsion was mixed with 3 volumes of a 1 in 10 dilution of alhydrogel. Each mouse received $0.1 \mathrm{ml}$ of this mixture intraperitoneally (i.p.) on days 0 and 14 . Blood was taken from the tail vein of each mouse on day 22 and the antibody response was measured by ELISA (see below) with an antigen consisting of whole cells grown in the presence of 2,2' dipyridyl. The mouse with the highest antibody titre was selected for fusion. Three days before fusion (day $30+$ ) the mouse was inoculated intravenously with heat-killed $P$. multocida $\left(10^{8}\right.$ cells) in $0 \cdot 1 \mathrm{ml}$ of saline. Fusion with NS- 0 cells was made by the method of Kohler and Milstein ${ }^{17}$ except that polyethylene glycol was used as the fusion agent. Hybridomas producing specific antibody were detected by a wholecell ELISA (see below) and were cloned and sub-cloned by limiting dilution.

Ascitic fluid was produced in adult BALB/c mice which had been primed i.p. with $0.5 \mathrm{ml}$ of pristane (Sigma) 3 days before an injection by the same route of $10^{7}$ hybridoma cells. Fluid was collected $7-10$ days later.

\section{Characterisation of MAbs}

Isotype determination. The class and subclass of the MAbs in culture supernates were determined by means of a mouse monoclonal-antibody isotyping kit (RPN29: Amersham International plc) according to the manufacturer's instructions.

Enzyme-linked immunosorbent assay (ELISA). An ELISA was used (a) to detect the antibody response of mice to vaccination, (b) to screen hybridomas for the production of specific antibody, and (c) to test the reactivity of MAbs against heterologous strains of bacteria. For purposes (a) and (b), P. multocida strain W674 was grown in NB containing 2,2'-dipyridyl for $6 \mathrm{~h}$ at $37^{\circ} \mathrm{C}$, washed once in phosphate-buffered saline (PBS) and resuspended in carbonate-bicarbonate buffer, $\mathrm{pH} 9 \cdot 6$, to a concentration $\left(10^{7} \mathrm{cfu} / \mathrm{ml}\right)$ previously shown by chess-board titration to be optimal for coating. For (c), an overnight culture of each strain was grown in NB, washed once in PBS and resuspended in formol saline $0.5 \%$ to c. $10^{7} \mathrm{cfu} / \mathrm{ml}(\mathrm{A} 420=0 \cdot 1)$. The wells of the microtitration plates were coated with $100 \mu$ l of bacterial suspension by incubating overnight at $4^{\circ} \mathrm{C}$. The primary antibody $(100 \mu l)$ was either undiluted hybridoma culture supernate or doubling dilutions of mouse serum, after an initial 1 in 50 dilution, in PBS containing Tween 20 $0.05 \%$ (PBST). After incubation for $1 \mathrm{~h}$ at $37^{\circ} \mathrm{C}$ and washing four times in PBST, 100- $\mu$ l volumes of horseradish peroxidase-sheep anti-mouse Ig conjugate (Scottish Antibody Production Unit, Carluke) diluted 1 in 200 in PBST were added and incubated for $1 \mathrm{~h}$ at $37^{\circ} \mathrm{C}$. After washing as previously, $100-\mu 1$ volumes of substrate solution (ortho-phenylenediamine, Sigma; $0.4 \mathrm{mg} / \mathrm{ml}$ in citrate phosphate buffer, $\mathrm{pH} 5$, with $30 \%$ hydrogen peroxide $4 \mu \mathrm{l} / 10 \mathrm{ml}$ ) were added and after $1 \mathrm{~h}$ at $37^{\circ} \mathrm{C}$ the colour was read at $492 \mathrm{~nm}$ in a Titertek Multiscan.

Immunoblotting. Whole-cell lysates of $P$. multocida strain W674 and Sarkosyl-extracted outer membranes prepared as described by Abdullahi et al. ${ }^{13}$ were separated on polyacrylamide $10 \%$ gels with the buffer system of Laemmli. ${ }^{18}$ LPS was prepared from several strains by the Proteinase K method of Hitchcock and Brown ${ }^{19}$ and separated on polyacrylamide $14 \%$ gels with the same buffer system as that for the $10 \%$ gels except that sodium dodecyl sulphate was omitted from the separating and stacking gel buffers. Separated antigens were transferred to nitrocellulose membranes (Schliecher and Schuell; pore size $0.2 \mu \mathrm{m}$ ) and probed with undiluted hybridoma culture supernates for $4 \mathrm{~h}$ at room temperature. Immune complexes were detected with anti-mouse Ig-horseradish peroxidase conjugate and the BioRad HRP colour reagent. ${ }^{20}$

Indirect haemagglutination (IHA). This was performed essentially by the method of Carter. ${ }^{21}$ Doubling dilutions of MAb (ascitic fluids), from 1 in 2 to 1 in 128, were tested against sheep red cells sensitised with capsular antigen prepared from the homologous strain W674 and several heterologous strains.

Bactericidal assay. MAbs were tested for their bactericidal capacity by the method of Wijewardana and Sutherland. ${ }^{22}$ Briefly, triplicate samples $(20 \mu 1)$ of MAb (ascitic fluid) were incubated with $100 \mu$ l of a suspension of strain W674 $(2000 \mathrm{cfu} / \mathrm{ml})$ in modified barbitone buffer (Sigma) for $10 \mathrm{~min}$ at room temperature in microtitration plates (tissue culture grade; NUNC, Denmark). After the addition of $80 \mu \mathrm{l}$ of undiluted fresh complement (serum from new-born calves or gnotobiotic lambs) to each well the plates were incubated for a further $30 \mathrm{~min}$ at $37^{\circ} \mathrm{C}$. From each well, triplicate $10-\mu \mathrm{l}$ samples were removed and plated on $7 \%$ sheep blood agar. The number of colonies $\left(\mathrm{T}_{30}\right)$ was counted after overnight incubation at $37^{\circ} \mathrm{C}$. The initial bacterial inoculum was confirmed retrospectively by plate counts ${ }^{23}$ and the assay count $\left(\mathrm{T}_{0}\right)$ was calculated as $0.5 \times$ the mean $\mathrm{cfu} / \mathrm{ml}$. The percentage killing $(\mathrm{K} \%)$ was then calculated by the formula:

$$
\mathrm{K} \%=1-\left[\frac{\text { mean cfu } / \mathrm{ml} \text { at } \mathrm{T}_{30}}{\text { mean cfu/ml at } \mathrm{T}_{0}}\right] \times 100
$$

Hyperimmune rabbit serum against strain W674 and fetal bovine serum were included as standard positive and negative sera respectively. The bactericidal capacity of the MAbs against heterologous strains was tested by the same method.

Passive protection of mice. The protective capacity of MAbs was investigated in BALB/c mice. Each MAb 
$(0.2 \mathrm{ml})$ in the form of ascitic fluid was inoculated into five mice. Ascitic fluid (0.2-ml volumes) of an irrelevant MAb (MAb E7, raised against louping-ill virus and kindly supplied by $\mathrm{Mr}$ M. Hussein of the Moredun Research Institute) was inoculated into five control mice. One hour later, all mice were challenged with approximately 10 LD50 of homologous or heterologous bacteria. ${ }^{13}$ Mice were observed for $48 \mathrm{~h}$ after challenge, deaths were recorded and the percentage protected was calculated.

\section{Results}

\section{Production and characterisation of monoclonal antibodies}

Of 97 hybridoma supernates tested in ELISA, 20 gave optical densities (OD) at $492 \mathrm{~nm}$ of greater than $0 \cdot 5$. However, only eight continued to produce specific antibody after cloning and these were characterised further.

Isotype determination. Four MAbs (1/2.16.8, $1 / 15.9 .1,1 / 18.13 .5$ and $1 / 20.10 .15)$ were of the IgM isotype, two $(1 / 4.1 .6$ and $1 / 19.12 .13)$ were $\operatorname{IgG}_{1}$, one $(1 / 13.6 / 12)$ was $\operatorname{IgG}_{2 b}$ and one (1/8.16.11) was $\mathrm{IgG}_{3}$.

a

\section{7}

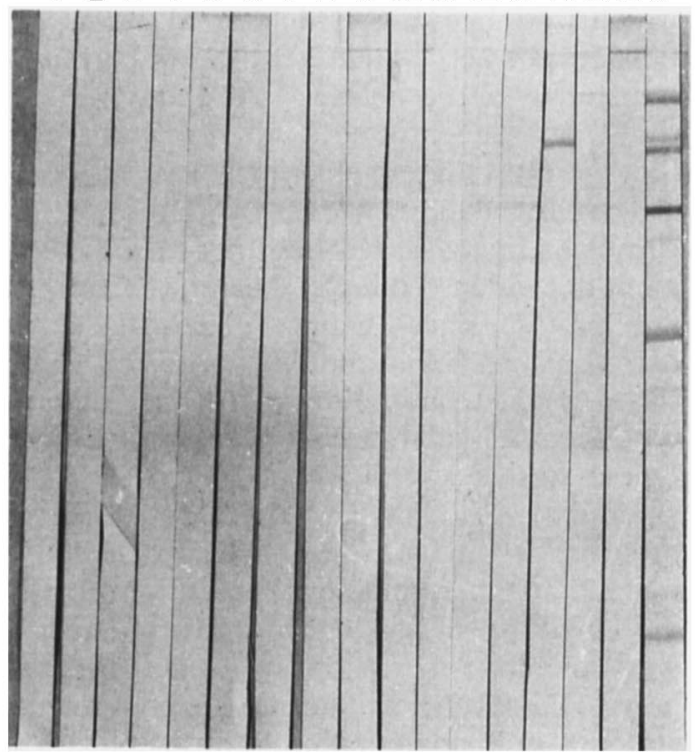

Immunoblotting. By this technique, only two MAbs were shown to react with separated, transferred antigens of the immunising strain W674. When the outer membranes were probed, only MAb 1/4.1.6 reacted (with a 77-Kda band; fig. 1a). However, when LPS was used, another MAb, $1 / 8.16 .11$, reacted strongly with the material at the gel front, which corresponded to LPS. This is shown in fig. 1b. Included in this figure are tracks probed with pre-cloned and pre-subcloned supernates.

Indirect haemagglutination. Only one MAb, $1 / 2.16 .8$, demonstrated haemagglutinating activity (titre of 64) and was considered to be reactive with a component of the capsule. Subsequently, when this MAb was tested with heterologous strains, it was found to be specific for the immunising strain.

Bactericidal activity. Complement-mediated bactericidal activity was demonstrated only by the anti-LPS MAb (1/8.16.11). There was $80 \%$ killing of the homologous strain.

Passive protection of mice. The group of mice that received the anti-LPS MAb (1/8.16.11) resisted challenge with 10 LD50 of strain W674 and remained well during the 48 -h observation period,

b
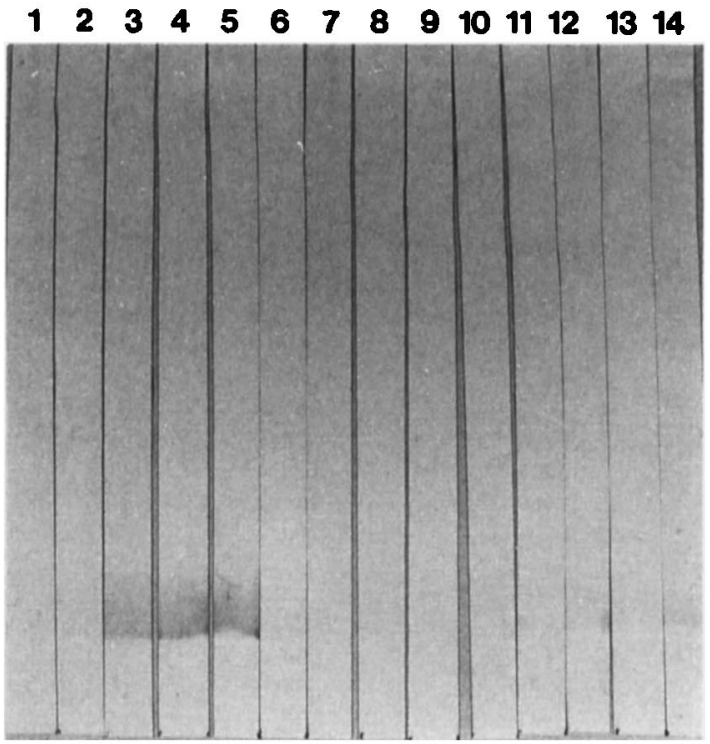

Fig. 1. Immunoblots of surface antigens of $P$. multocida strain W674 probed with undiluted hybridoma culture supernates. (a) Sarkosyl-prepared outer-membrane proteins: the only tracks showing positive reactions compared with the negative control (track 16, uninoculated culture medium) are 14 and 17, which correspond to MAb 1/4.1.6 and the positive control (serum from the mouse used for fusion) respectively. (b) LPS: the tracks showing strong, positive reactions were probed with MAb 1/8.16.11 (track 5), and supernates from the uncloned primary hybridoma culture well (track 3 ) and the first cloning of this culture (track 4); the serum from the mouse chosen for fusion is in track 14 , and shows a weak positive reaction. 
indicating $100 \%$ protection; all the control mice died. In the groups of mice inoculated with MAbs $1 / 19.12 .13$ and $1 / 20.10 .15$, two and five animals respectively were alive at the end of the observation period but they were severely ill. After killing the surviving mice by cervical dislocation, heart blood was plated on sheep blood agar. $P$. multocida was recovered from the sick mice but not from the mice protected with the anti-LPS MAb.

\section{Reaction of anti-LPS MAb with heterologous strains}

From the results described above, it was evident that the anti-LPS MAb (1/8.16.11) protected mice against homologous challenge and promoted complement-mediated killing. Therefore, this MAb was tested against heterologous strains in the whole-cell ELISA, in immunoblotting with LPS preparations, in bactericidal assays and by passive protection tests in mice.

The whole-cell ELISA results and the bactericidal capacities are shown in table I. The absorbances of

Table I. Bactericidal capacity of the anti-LPS MAb (1/8.16.11) against strains of $\boldsymbol{P}$. multocida and the corresponding ELISA absorbances

\begin{tabular}{|c|c|c|}
\hline \multirow[b]{2}{*}{$\begin{array}{l}\text { Strain of } P . \text { multo- } \\
\text { cida }\end{array}$} & \multicolumn{2}{|c|}{$\begin{array}{c}\text { Reactions of anti-LPS MAb with } \\
\text { P. multocida strains }\end{array}$} \\
\hline & $\begin{array}{l}\text { Bacterial } \\
\text { killing }(\%)\end{array}$ & $\begin{array}{c}\text { ELISA absorbances } \\
(\%) \dagger\end{array}$ \\
\hline$X 1056^{*}$ & $100 \cdot 0$ & $91 \cdot 6$ \\
\hline A36* & $100 \cdot 0$ & $97 \cdot 0$ \\
\hline A1174* & $100 \cdot 0$ & $119 \cdot 2$ \\
\hline A $757^{*}$ & $71 \cdot 7$ & $91 \cdot 6$ \\
\hline $\mathrm{X} 120^{*}$ & $100 \cdot 0$ & $62 \cdot 0$ \\
\hline $\mathrm{X} 110^{*}$ & $78 \cdot 8$ & $92 \cdot 0$ \\
\hline W674* & $95 \cdot 8$ & $100 \cdot 0$ \\
\hline W666* & $100 \cdot 0$ & $91 \cdot 2$ \\
\hline $\mathrm{X} 1053^{*}$ & $80 \cdot 0$ & $95 \cdot 7$ \\
\hline A341* & $100 \cdot 0$ & $102 \cdot 6$ \\
\hline $\mathrm{Q} 110$ & $12 \cdot 0$ & $11 \cdot 5$ \\
\hline Type A (10322) $\ddagger$ & $0 \cdot 0$ & $14 \cdot 3$ \\
\hline Type B (10323)‡ & $5 \cdot 0$ & 14.9 \\
\hline Type D (10325) $\ddagger$ & 0.0 & $12 \cdot 4$ \\
\hline Type E (10326) & 0.0 & $8 \cdot 2$ \\
\hline A848 & 0.0 & $9 \cdot 3$ \\
\hline $\mathrm{X} 1016$ & 0.0 & $17 \cdot 1$ \\
\hline A26 & 0.0 & $10 \cdot 4$ \\
\hline A419 & 0.0 & $14 \cdot 4$ \\
\hline A586 & 0.0 & $16 \cdot 0$ \\
\hline
\end{tabular}

*Strains that reacted with MAb in immunoblotting. †ELISA absorbance values relative to the homologous (strain W674) reaction.

$\$$ NCTC numbers. heterologous strains are expressed as percentages of the $\mathrm{OD}_{492}$ of the homologous strain. Correlation between percentage killing and percentage absorbance, determined by the Spearman-Jackson rank correlation test, was highly significant $(p<0.001)$.

Immunoblots of LPS from 20 heterologous strains showed that 10 strains reacted strongly with the anti-LPS MAb and 10 did not (fig. 2). These reactions correlated with the ELISA and the bactericidal results. Fig. 3 shows that silver-stained polyacrylamide gels of the LPS preparations were all similar and resembled rough LPS of the enterobacteria.

The passive protection afforded by the anti-LPS $\mathrm{MAb}$ against six heterologous strains - five of which reacted in ELISA and in immunoblotting and one (strain A848) which did not-is shown in table II. The only strain against which no protection was obtained was A848; this strain was not killed by complement-mediated bactericidal activity. Protection was $60-100 \%$ against the other strains.

\section{Discussion}

Of the eight MAbs that reacted in ELISA to whole bacteria, three were characterised further and shown by immunoblotting to be specific for LPS, capsule and an OMP respectively. The other five MAbs did not react in immunoblotting or IHA and were probably directed against protein epitopes which were irreversibly denatured during separation on polyacrylamide gel electrophoresis or on transfer to nitrocellulose. ${ }^{24}$ As these MAbs were shown subsequently not to be protective in mice they were not investigated further.

The MAb that reacted only with the homologous capsular antigen in IHA did not mediate complement-dependent killing of bacteria in vitro. It did not protect mice against challenge with live organisms and was probably directed against a strain-specific surface antigen rather than to the type-specific hyaluronic acid capsule common to all type-A strains of $P$. multocida.

Similarly, the anti-77 Kda OMP MAb did not protect mice and was not bactericidal. Lu et al. ${ }^{14}$ found that hyperimmune rabbit antiserum containing a high titre of IgG antibody to a $37 \cdot 5-\mathrm{Kda}$ OMP was protective in rabbits. However, they used a polyclonal serum containing antibody to several epitopes in a single molecule rather than a $\mathrm{MAb}$ defining a single epitope.

The most significant finding of the present study was that anti-LPS $\operatorname{IgG}_{3}$ MAb protected mice against homologous and heterologous challenge by a mechanism associated with complement-depend- 


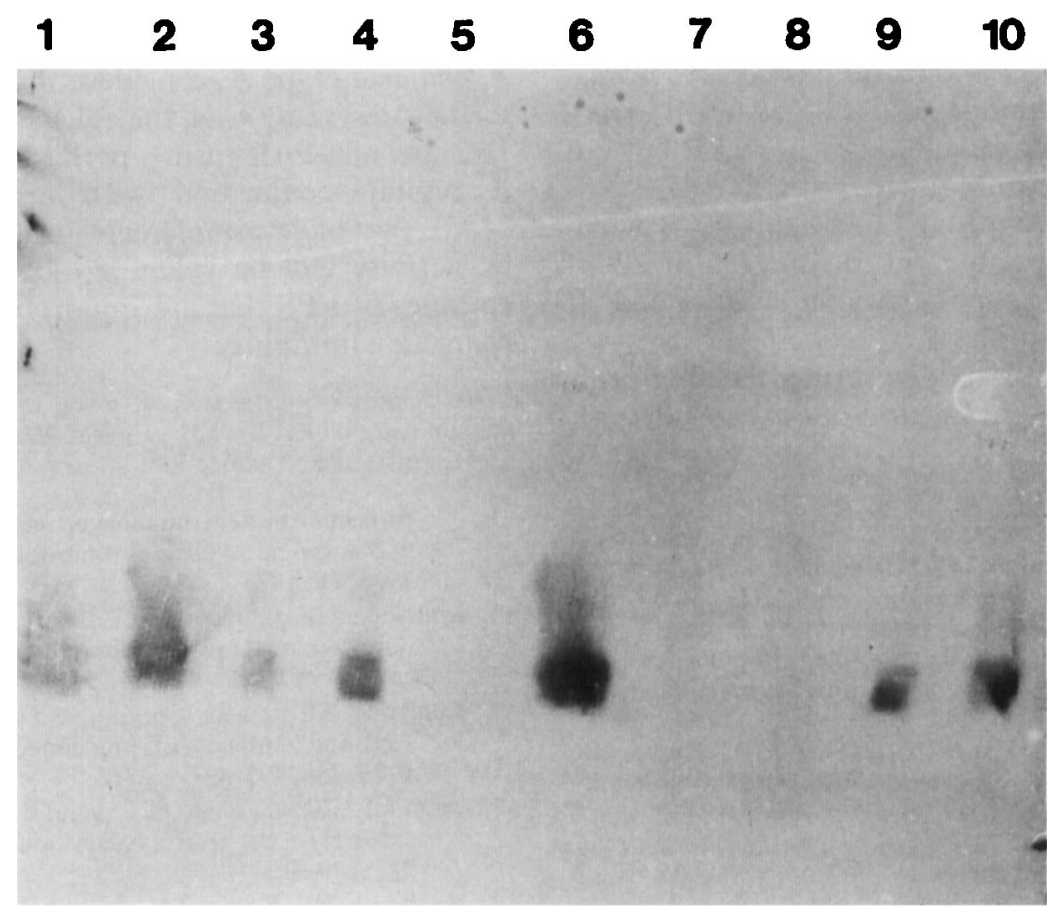

Fig. 2. Examples of immunoblots of LPS from homologous (track 9) and heterologous strains of $P$. multocida type A probed with anti-LPS MAb 1/8.16.11 diluted 1 in 2. Track 1 , strain A757; 2, A36; 3, X110; 4, X1056; 5, A848; 6, W666; 7, Q110; 8, X1016; 9, W674; 10, X120.
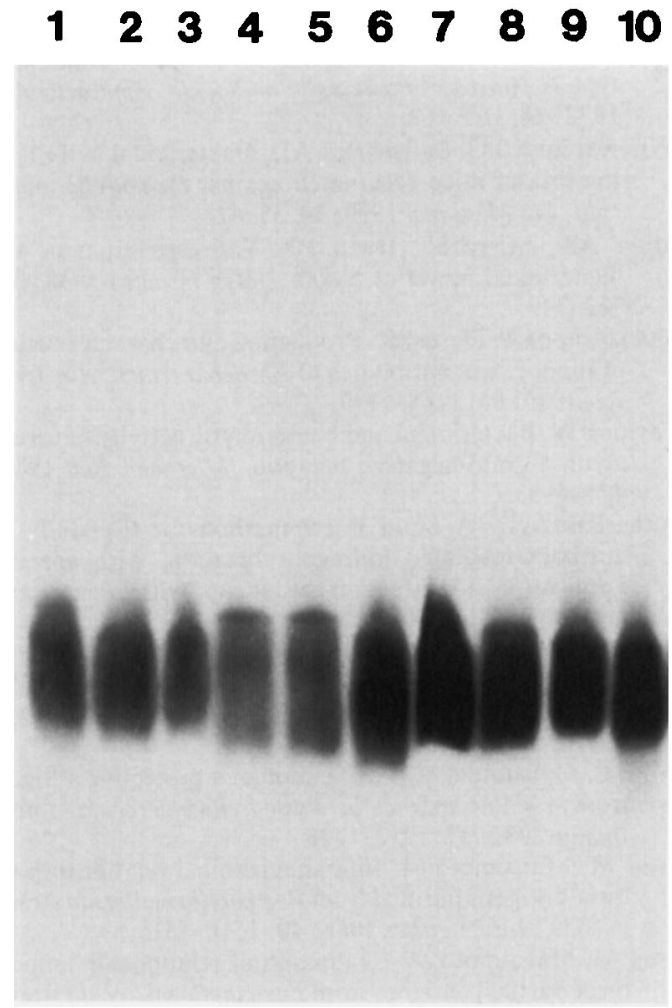

Fig. 3. Silver-stained LPS from 10 strains of $P$. multocida type A on polyacrylamide $14 \%$ gels. The order is as in fig. 2 . ent antibody-mediated bacterial killing. An investigation of the bactericidal activity of serum from vaccinated mice ${ }^{22}$ suggested that a cell-surface antigen was associated with this mechanism of immunity, because the bactericidal capacity of mouse polyclonal serum was closely correlated $(\mathrm{p}<$ 0.001) with whole-cell ELISA titres. It is clear that anti-LPS antibodies play a major role in immunity in mice by participating in complement-mediated bacteriolysis. This agrees with earlier views. ${ }^{25,26}$

In addition, the LPS of $P$. multocida type A has been identified as an important immunogen when

Table II. The activity of the anti-LPS MAb in passive protection of mice challenged with heterologous strains

\begin{tabular}{lc|c}
\hline \multicolumn{2}{c|}{ Challenge strains } & $\begin{array}{c}\text { Number of survivors in } \\
\text { groups of five mice }\end{array}$ \\
\hline No. & LD50 & \\
\hline A36 & $4.8 \times 10^{6}$ & 3 \\
X110 & $3.6 \times 10^{5}$ & 3 \\
X1053 & $8.8 \times 10^{6}$ & 3 \\
A341 & $6.3 \times 10^{5}$ & 5 \\
A1174 & $6.1 \times 10^{6}$ & 4 \\
A848 & $1.9 \times 10^{3}$ & 0 \\
\hline
\end{tabular}

Mice were challenged with $c$. 10 LD50. 
conjugated with protein in chickens, mice and rabbits. ${ }^{8-10,27-30}$ To induce immunity, ribosomal vaccines should contain LPS. ${ }^{11,12}$ An LPS-ribosome complex gave an enhanced humoral but not cell-mediated immunity in chickens. ${ }^{12}$

The epitope recognised by the anti-LPS MAb was found to be present on the surface of about $50 \%$ of the capsule type-A strains investigated. It will be of interest to define the chemical structure of this epitope and to determine whether it is specific to one or more $\mathrm{O}$ serotypes in capsule typeA strains.

\section{REFERENCES}

1. Carter GR. Pasteurellosis: Pasteurella multocida and Pasteurella hemolytica. Adv Vet Sci 1967; 11: 321-379.

2. Manning PJ. Naturally occurring pasteurellosis in laboratory rabbits: chemical and serological studies of whole celis and lipopolysaccharides of Pasteurella multocida. Infect Immun 1984; 44: 502-507.

3. Bain RVS, De Alwis MCL, Carter GR, Gupta BK. Haemorrhagic septicaemia. FAO Animal Production and Health Paper, No. 33, FAO, Rome, 1982.

4. Rutter JM. Atrophic rhinitis in swine. Adv Vet Sci Comp Med 1985; $29: 239-279$.

5. Nagy LK, Penn CW. Protection of cattle against experimental haemorrhagic septicaemia by the capsular antigens of Pasteurella multocida, types B and E. Res Vet Sci 1976; 20 : 249-253.

6. Heddleston KL, Watco LP, Rebers PA. Dissociation of a fowl cholera strain of Pasteurella multocida. Avian Dis 1964; 8: 649-657.

7. Brogden KA, Rebers PA. Serologic examination of the Westphal-type lipopolysaccharides of Pasteurella multocida. Am J Vet Sci 1978; 39: 1680-1682.

8. Rebers PA, Phillips M, Rimler R, Boykins RA, Rhoades KR. Immunizing properties of Westphal lipopolysaccharide from an avian strain of Pasteurella multocida. Am J Vet Res 1980; 41 : 1650-1654.

9. Rebers PA, Heddleston KL. Immunogenic comparison of Westphal-type lipopolysaccharides and free endotoxins from an encapsulated and nonencapsulated avian strain of Pasteurella multocida. Am J Vet Res 1974 ; 35 : 555560.

10. Ganfield DJ, Rebers PA, Heddleston KL. Immunogenic and toxic properties of a purified lipopolysaccharideprotein complex from Pasteurella multocida. Infect Immun 1976; 14: 990-999.

11. Phillips M, Rimler RB. Protection of chickens by ribosomal vaccines from Pasteurella multocida: dependence on homologous lipopolysaccharide. Am J Vet Res 1984; 45: $1785-1789$.

12. Rimler RB, Phillips M. Fowl cholera: protection against Pasteurella multocida by ribosome-lipopolysaccharide vaccine. Avian Dis $1986 ; 30: 409-415$.

13. Abdullahi MZ, Gilmour NJL, Poxton IR. Outer membrane proteins of bovine strains of Pasteurella multocida type $\mathrm{A}$ and their doubtful role as protective antigens. $J \mathrm{Med}$ Microbiol 1990; 32: 55-61.

14. Lu Y-S, Afendis SJ, Pakes SP. Identification of immunogenic outer membrane proteins of Pasteurella multocida 3.A in rabbits. Infect Immun 1988; 56: 1532-1537.

15. Lu Y-S, Gerrity LW, Afendis SJ, Watkins L, Pakes SP. Distribution of a monoclonal antibody-recognized
In any future work on vaccine development for $P$. multocida type A, consideration should be given to the presentation of the relevant epitope of the LPS in a non-toxic form-perhaps free of the lipidA region-conjugated with protein. Anti-LPS MAbs that have complement-mediated bacteriolytic activity will be valuable tools in defining the epitopes of LPS that are important in stimulating protective immunity.

We acknowledge the support given to T.G.W. by the Sri Lankan Agricultural Research Project. We thank A.D. Sutherland for his help and advice.

protective protein immunogen on the outer membranes of Pasteurella multocida rabbit isolates. J Clin Microbiol 1988; 26: 1326-1330.

16. Abdullahi MZ, Gilmour NJL, Poxton IR. Identification of non-haemolytic pasteurellae cultured from the lungs of cattle. Vet Rec 1989; 125 : 154.

17. Köhler G, Milstein C. Continuous cultures of fused cells secreting antibody of predefined specificity. Nature 1975 ; 256 : 495-497.

18. Laemmli UK. Cleavage of structural proteins during the assembly of the head of bacteriophage T4. Nature 1970; 227: 680-685.

19. Hitchcock PJ, Brown TM. Morphological heterogeneity among Salmonella lipopolysaccharide chemotypes in silver-stained polyacrylamide gels. J Bacteriol 1983; 154: 269-277.

20. Hancock IC, Poxton IR. Bacterial cell surface techniques. Chichester, Wiley. 1988: 202-207.

21. Carter GR. Improved hemagglutination test for identifying type A strains of Pasteurella multocida. Appl Microbiol $1972 ; 24: 162-163$.

22. Wijewardana TG, Sutherland AD. Bactericidal activity in the sera of mice vaccinated against Pasteurella multocida. Vet Microbiol 1990; 24, 55-62.

23. Miles AA, Misra SS, Irwin JO. The estimation of the bactericidal power of blood. J Hyg (Camb) 1938; 38: $732-749$.

24. Shankarappa B, Dutta SK. Production and characterisation of monoclonal antibodies to Ehrlichia risticii. Am J Vet Res 1989; 50: 1145-1149.

25. Taylor PW. Bactericidal and bacteriolytic activity of serum against gram-negative bacteria. Microbiol Rev 1983; 47: 46-83.

26. Sutherland AD. A rapid micro-method for the study of antibody-mediated killing of bacteria, with specific application to infection of sheep with Pasteurella haemolytica. Vet Microbiol 1988; 16: 263-271.

27. Heddleston KL, Gallagher JE, Rebers PA. Fowl cholera: gel diffusion precipitin test for serotyping Pasteurella multocida from avian species. Avian Dis 1972; 16: 925936.

28. Syuto B, Matsumoto M. Purification of a protective antigen from a saline extract of Pasteurella multocida. Infect Immun 1982; 37: 1218-1226.

29. Tsuji $\mathbf{M}$, Matsumoto $\mathbf{M}$. Immunochemical relationship of three antigens purified from Pasteurella multocida strain P-1059. Am J Vet Res 1988; 49: 1510-1515.

30. Tsuji $\mathbf{M}$, Matsumoto $\mathbf{M}$. Evaluation of relationship among three purified antigens from Pasteurella multocida strain P-1059 and of their protective capacities in turkeys. Am $J$ Vet Res 1988; 49: 1516-1521. 